GRASAS Y ACEITES 67 (4)

October-December 2016, e168

ISSN-L: 0017-3495

doi: http://dx.doi.org/10.3989/gya.0571161

\title{
Enzymatic preparation and characterization of soybean lecithin-based emulsifiers
}

\author{
R.C. Reddy Jala ${ }^{\mathrm{a}, \mathrm{b}, \varpi}$, B. Chen ${ }^{\mathrm{a}}$, H. Li ${ }^{\mathrm{a}}$, Y. Zhang ${ }^{\mathrm{a}}$, L-Z Cheong ${ }^{\mathrm{a}}$, T.Yang ${ }^{\mathrm{a}}$ and X. Xu \\ ${ }^{a}$ Wilmar (Shanghai) Biotechnology R\&D Centre Co., Pudong New District, 200137 Shanghai, China \\ ${ }^{b}$ Centre for Lipid Research, CSIR-Indian Institute of Chemical Technology, Hyderabad, \\ 500007 , India \\ ${ }^{\otimes}$ Corresponding author: jrcreddy10@gmail.com; ramchandra@iict.res.in
}

Submitted: 30 May 2016; Accepted: 19 September 2016

\begin{abstract}
SUMMARY: Simple enzymatic methods were developed for the synthesis of lysolecithin, glycerolyzed lecithin and hydrolyzed lecithin. The products were characterized in terms of their acetone insoluble matter, hexane insoluble matter, moisture, phospholipid distribution and fatty acid composition. The HLB value ranges of different products with different acid values were detected. The efficiency of optimally hydrolyzed lecithin was examined at high calcium ion, low $\mathrm{pH}$, and aqueous solutions and compared with commercially available standard lecithin-based emulsifiers. Overall, lysolecithin powder was proven to be the best emulsifier even at strong and medium acidic conditions.
\end{abstract}

KEYWORDS: Concentrated lecithin; Glycerolyzed lecithin; Hydrolyzed lecithin; Lysolecithin; Powdered lecithin

RESUMEN: Preparación enzimática y caracterización de emulsionantes a base de lecitina de soja. Se han desarrollado métodos enzimáticos simples para la síntesis de lisolecitina, lecitina esterificada a glicerol y lecitina hidrolizada. Los productos se caracterizaron en términos de su composición en materia insoluble en acetona, materia insoluble en hexano, humedad, distribución de fosfolípidos y ácidos grasos. Además, se detectaron rangos de los valores de HLB de diferentes productos con valores de ácido diferentes. La eficiencia de la lecitina hidrolizada de forma óptima fue estudiada en función de una alta concentración de ion calcio, pH bajo, y soluciones acuosas y se compara con emulsionantes basados en lecitina estándar disponibles en el mercado. En general, el polvo de lisolecitina mostró ser el mejor emulsionante incluso en condiciones ácidas fuertes y medias.

PALABRAS CLAVE: Lecitina concentrada; Lecitina en polvo; Lecitina esterificada a glicerol; Lecitina hidrolizada; Lisolecitina

Citation/Cómo citar este artículo: Reddy Jala RC, Chen B, Li H, Zhang Y, Cheong L-Z, Yang T, Xu X. 2016. Enzymatic preparation and characterization of soybean lecithin-based emulsifiers. Grasas Aceites 67, e168. http://dx.doi. org/10.3989/gya.0571161.

Copyright: (C2016 CSIC. This is an open-access article distributed under the terms of the Creative Commons Attribution (CC-by) Spain 3.0 License.

\section{INTRODUCTION}

Lecithins and their partially hydrolyzed/modified products have found numerous applications in food, pharmaceutical and personal care industries due to their superior emulsification properties
(Nieuwenhuyzen, 1981; Nieuwenhuyzen and Tomas, 2008; Aoi, 1990; Fujita and Suzuki, 1990). The most widely used lyso phospholipids (LPLs) is lysolecithin, which is obtained through hydrolysis of one fatty acyl residue from lecithin (Nakai et al., 1988; Kudo and Nishi, 1990; Yesair, 1997; Kim et al., 1997; 
Haas et al., 1994; Sarney et al., 1994; Mustranta et al., 1995). Conventional methods of fat hydrolysis were reported to be inappropriate for phospholipids (PLs) as the high temperature and pressure reaction caused fouling of reactors (Haas et al., 1993).

Structural modification of PLs had been made consistently to achieve beneficial nutritional and functional properties. It can be achieved enzymatically by using phospholipases and lipases in reactions such as hydrolysis, alcoholysis, esterification, transesterification, and transphosphatidylation. Enzymatic reactions offer a non-destructive and energy efficient route for PL hydrolysis. Therefore, numerous phospholipases $\mathrm{A}_{1}\left(\mathrm{PLA}_{1}\right)$ and $\mathrm{A}_{2}\left(\mathrm{PLA}_{2}\right)$ have been identified, and their abilities to hydrolyze the fatty acyl ester bonds of PL have been characterized (de Maria et al., 2007).

The addition of mono- and diglycerides to lecithins or partially hydrolyzed lecithins has been found to improve functional properties such as baking performance, anti-spattering and anti-staling. Modified lecithins have been used in food and feed products such as frozen dough, bakery products, emulsified meat products, ice cream, dressings and other emulsion systems (Schmitt et al., 2005). Presently lecithin-based products enriched with mono- and diglycerides are prepared by the addition of mono- and diglycerides to lecithins. However, the direct preparation of mono and diglyceride-rich lecithin products in a controlled manner through enzymatic hydrolysis and glycerolysis would be useful. Therefore, the present study attempts to prepare such products and the products were characterized for their composition. Further, the optimally hydrolyzed product was evaluated for its emulsifying efficiency and compared with commercially available standard lecithin-based emulsifiers.

\section{MATERIALS AND METHODS}

\subsection{Materials}

Concentrated soybean lecithins, and crude gum solution were donated by Qinhuangdao Golden Sea Industry, Beijing, China. Powdered lecithins were obtained from the ADM (Shanghai, China). They were stored at $-20{ }^{\circ} \mathrm{C}$ until the de-oiling or modification process. Organic solvents (Analytical and HPLC grade) and chemicals (glycerol and calcium chloride) were purchased from Sinopharm Chemical Reagent Co., Ltd., (Shanghai, China). For column chromatography, silica gel (60-120, 100-200 mesh particle size) was purchased from Qingdao Haiyang Chemical Co., Ltd., (Qingdao, China). Certified standard materials phosphatidylcholine (L- $\alpha-\mathrm{PC}), \quad$ phosphatidylethanolamine (L- $\alpha-\mathrm{PE})$, phosphatidylinositol (L- $\alpha-\mathrm{PI})$ from soybean and phosphatidic acid (L- $\alpha$-PA) with purities greater than $98 \%$ were obtained from Sigma Chemical Co.
(Shanghai, China). Lecitase Ultra [Phospholipase $\mathrm{A}_{1} \quad \mathrm{PLA}_{1}$, E.C.3.1.1.32)] from Aspergillus oryzae $(10,000 \mathrm{U} / \mathrm{mL})$ and Candida antarctica lipase (CAL) B were purchased from Novozymes A/S (Tianjin, China). The term CALB-PLA $A_{1}$ means the

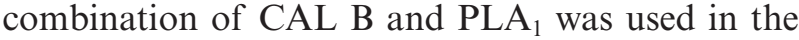
reaction. The PL compositions of concentrated lecithin, aqueous-hydrolyzed lecithins (lysolecithin-1), solvent-hydrolyzed lecithins (lysolecithin-2) and glycerolyzed lecithin were different from each other (Table1). Concentrated lecithin contains approximately equal amounts of PC, PE and PI $(\sim 30 \%)$ and a small amount of PS $(<10 \%)$. After the enzymatic hydrolysis and glycerolysis the amount of Lyso PLs had increased $(>50 \%)$ in lysolecithin 1 , lysolecithin 2 and glycerolyzed lecithins.

\subsection{Methods}

\subsubsection{Characterization of the concentrated soybean lecithin}

Concentrated soybean lecithin was characterized in terms of acetone-insoluble matter, hexaneinsoluble matter, humidity (moisture content) and acid value according to the AOCS official methods (Ja 4-46, Ja 3-87, Ja 2b-87, Ja 6-55) (AOCS, 2001). Phospholipid composition was determined using HPLC-ELSD (Model: Agilent 1100, Agilent, Beijing, China) according to Becart et al., (1990). HPLC (Agilent 1100) equipped with a silica gel column (Lichrospher Si 60,5 $\mu \mathrm{m}, 12 \mathrm{~cm} \times 4 \mathrm{~mm}$, Merck) and evaporative light scattering detector (ELSD, Alltech 3300) was used. Eluent A was chloroform/methanol/ammonium hydroxide, 80/19.5/0.5 (v/v/v) and eluent B was chloroform/methanol/ water/ammonium hydroxide, 60/34/5.5/0.5 (v/v/v/v). The gradient was: 0-14 min: linear from A/B, 50/50 to $100 \% \mathrm{~B}, 14-25 \mathrm{~min}$ : hold $100 \% \mathrm{~B}, 25-30 \mathrm{~min}$ : $100 \% \mathrm{~B}$ to $\mathrm{A} / \mathrm{B}, 50 / 50$ and $15 \mathrm{~min}$ at $\mathrm{A} / \mathrm{B}, 50 / 50$ for column regeneration. The flow rate of the eluent was $1 \mathrm{~mL} / \mathrm{min}$. The pressure of the nebulizer gas (air) at ELSD was maintained at 3.2 bars and the drift tube temperature was set at $40{ }^{\circ} \mathrm{C}$. The column temperature was also set at $40{ }^{\circ} \mathrm{C}$. Samples $(10$ $\mathrm{mg}$ ) were dissolved in $10 \mathrm{~mL}$ chloroform/methanol/ water (70/25/5). $20 \mu \mathrm{L}$ of the sample were injected into the HPLC. The sample $(10 \mathrm{mg})$ was dissolved in $(10 \mathrm{~mL})$ chloroform-methanol (2:1) solution. $20 \mu \mathrm{L}$ of the sample were injected into the HPLC. Analyses were performed in triplicate. The retention times of phosphatidylethanolamine (PE), phosphatidylinositol (PI), lysophosphatidylethanolamine (Lyso PE), phosphatidylcholine (PC), lysophosphatidylcholine (Lyso PC) and phosphatidic acid (PA) were approximately $5.0,7.0,8.0,8.8,9.5$ and $14.5 \mathrm{~min}$, respectively. The percentages of individual constituents were also confirmed by quantitative column chromatography. Lecithin fatty acid composition was 
TABLE 1. Characterization of concentrated soybean lecithin and modified lecithin

\begin{tabular}{|c|c|c|c|c|}
\hline & $\begin{array}{c}\text { Concentrated } \\
\text { soybean lecithin }\end{array}$ & Lysolecithin 1* & Lysolecithin 2* & $\begin{array}{c}\text { Glycerolyzed } \\
\text { lecithin }\end{array}$ \\
\hline Acetone insoluble matter ${ }^{\mathrm{a}}(\%)$ & $63.2 \pm 0.4$ & $49.7 \pm 0.4$ & $52.3 \pm 0.4$ & $54.1 \pm 0.4$ \\
\hline Hexane insoluble matter ${ }^{\mathrm{a}}(\%)$ & $1.9 \pm 0.01$ & $2.0 \pm 0.01$ & $2.0 \pm 0.01$ & $2.0 \pm 0.01$ \\
\hline Moisture (Air oven method) ${ }^{\mathrm{a}}(\%)$ & $3.1 \pm 0.2$ & $4.5 \pm 0.2$ & $4.3 \pm 0.3$ & $4.2 \pm 0.3$ \\
\hline Acid value $^{\mathrm{a}}$ (mg KOH/g) & $27.3 \pm 2.1$ & $60 \pm 2.3$ & $55 \pm 2.1$ & $54 \pm 2.0$ \\
\hline \multicolumn{5}{|l|}{ Phospholipid distribution ${ }^{\mathrm{a}}(\%)$} \\
\hline $\mathrm{PC}$ & $30.8 \pm 2.1$ & $11 \pm 1.1$ & $15.9 \pm 1.9$ & $8.8 \pm 1.2$ \\
\hline $\mathrm{PE}$ & $32.5 \pm 0.2$ & $15.2 \pm 1.6$ & $20.7 \pm 0.8$ & $12.8 \pm 1.7$ \\
\hline PI & $27.9 \pm 0.3$ & $16.7 \pm 0.7$ & $18.7 \pm 1.5$ & $15.7 \pm 0.8$ \\
\hline PA & $8.8 \pm 0.5$ & $8.0 \pm 0.9$ & $8.7 \pm 0.7$ & $6.9 \pm 0.9$ \\
\hline Lyso PC & - & $19.7 \pm 1.9$ & $14.8 \pm 1.2$ & $22.2 \pm 2.1$ \\
\hline Lyso PE & - & $17.4 \pm 1.2$ & $11.8 \pm 1.1$ & $19.9 \pm 1.1$ \\
\hline Lyso PI & - & $11.2 \pm 0.9$ & $9.2 \pm 0.9$ & $12.0 \pm 1.1$ \\
\hline Lyso PA & - & $0.8 \pm 0.3$ & $0.2 \pm 0.2$ & $1.7 \pm 0.2$ \\
\hline \multicolumn{5}{|l|}{ Fatty-acid profile $(\%)$} \\
\hline C16:0 & $20.4 \pm 1.5$ & $20.3 \pm 1.6$ & $20.3 \pm 1.5$ & $20.2 \pm 1.4$ \\
\hline C18:0 & $4.6 \pm 0.1$ & $4.5 \pm 0.1$ & $4.6 \pm 0.1$ & $4.4 \pm 0.1$ \\
\hline C18:1 & $9.5 \pm 0.2$ & $9.6 \pm 0.2$ & $9.5 \pm 0.2$ & $9.7 \pm 0.2$ \\
\hline $\mathrm{C} 18: 2$ & $57.6 \pm 2.5$ & $57.7 \pm 2.4$ & $57.6 \pm 2.3$ & $57.6 \pm 2.3$ \\
\hline C18:3 & $7.9 \pm 0.1$ & $7.9 \pm 0.1$ & $8.0 \pm 0.1$ & $8.1 \pm 0.1$ \\
\hline Unsaturated/saturated ratio & 3.0 & 3.0 & 3.0 & 3.0 \\
\hline
\end{tabular}

${ }^{a}$ Arithmetic means of triplicate determinations with their confidence interval at $95 \%$.

${ }^{\mathrm{b}}$ Arithmetic means of duplicate determinations.

*Lysolecithin 1: aqueous-hydrolyzed lyso lecithin.

*Lysolecithin 2: solvent-hydrolyzed lyso lecithin.

determined by gas chromatography (Model: Agilent HP6890, Agilent, Beijing, China) according to the AOCS Ce 2-66 method (AOCS, 2001). Analyses were performed in duplicate.

\subsubsection{De-oiling of the concentrated soybean lecithin}

De-oiled lecithin was prepared from concentrated soybean lecithin through acetone- fractionation. Concentrated soybean lecithin was repeatedly extracted with cold acetone at $0^{\circ} \mathrm{C}$ (acetone/gum ratio of $5: 1 \mathrm{v} / \mathrm{w}$; stirred for $30 \mathrm{~min}$ at $400 \mathrm{rpm}$ for 3 times). The acetone solution fractions were subjected to centrifugation. After decantation of the acetone soluble part, the insoluble matter (PLs) located at the bottom of the centrifugation tube was collected and solvent traces were evaporated under vacuum conditions.

\subsubsection{Preparation of lysolecithin (lysolecithin 1) through PLA1-catalyzed hydrolysis in aqueous medium}

Concentrated soybean lecithin $(50 \mathrm{~g})$ and water $(100 \mathrm{~mL})$ were heated to 30 and $50^{\circ} \mathrm{C}$, respectively. They were then mixed and magnetically stirred for a period of 15 mins (with $400 \mathrm{rpm}$ speed). The reaction was initiated by the addition of $\mathrm{PLA}_{1}$ enzyme solution $(0.5 \%$; w/w of lecithin). The reaction was conducted at $50^{\circ} \mathrm{C}$ for $25 \mathrm{~min}$. All the reactions were carried out in duplicate. Aliquots $(4 \mathrm{~mL})$ were withdrawn from the reaction mixture at regular intervals for analysis of acid value according to the AOCS official method (Ja 6-55) (AOCS, 2001). At the end of the reaction, the reaction mixtures were heated at $110^{\circ} \mathrm{C}$ for $30 \mathrm{~min}$ to inactivate the enzyme. Subsequently, the water was evaporated from the reaction mixture at $80^{\circ} \mathrm{C}$ for $1 \mathrm{~h}$.

\subsubsection{Preparation of lysolecithin (lysolecithin 2) through PLA1-catalyzed hydrolysis in solvent medium}

Concentrated soybean lecithin $(50 \mathrm{~g})$ and solvents (100 mL tert-butanol/hexane) were heated at 50 and $60{ }^{\circ} \mathrm{C}$, respectively. They were then mixed with stirring at $400 \mathrm{rpm}$ with a magnetic bar. The reaction was initiated by the addition of PLA enzyme $_{1}$ solution $(0.5 \%$; w/w of lecithin). The reaction was conducted at $60^{\circ} \mathrm{C}$ for about $6 \mathrm{~h}$. All the reactions were carried out in duplicate. Aliquots $(4 \mathrm{~mL})$ were withdrawn from the stirred reaction mixture at regular intervals for analysis of acid value according to 
the AOCS official method (Ja 6-55) (AOCS, 2001). At the end of the reaction, the reaction mixtures were heated at $110{ }^{\circ} \mathrm{C}$ for 30 min to inactivate the enzyme. After that, the solvent was evaporated from the reaction mixture at $60^{\circ} \mathrm{C}$ for $1 \mathrm{~h}$.

\subsubsection{CAL B-PLA1 catalyzed glycerolysis of lecithin}

Concentrated soybean lecithin $(50 \mathrm{~g})$ and glycerol $(25 \mathrm{~g})$ at a molar ratio of $1: 4.5$, tert-butanol $(75 \mathrm{~g}$, $100 \mathrm{wt} \%$ of total substrates) and water $(7.5 \mathrm{~g}, 10 \mathrm{wt}$ $\%$ of total substrates) were mixed and mechanically stirred $(500 \mathrm{rpm})$ at $50{ }^{\circ} \mathrm{C}$. The reaction was initiated by adding a CAL B solution ( $5 \mathrm{wt} \%$ of lecithin) and $\mathrm{PLA}_{1}$ solution ( $5 \mathrm{wt} \%$ of lecithin). The reaction mixture was incubated at $50{ }^{\circ} \mathrm{C}$ for $8 \mathrm{~h}$. At the end of the reaction, the reaction mixture was heated at $110^{\circ} \mathrm{C}$ for $30 \mathrm{~min}$ to deactivate the enzymes. Solvent was evaporated at $60{ }^{\circ} \mathrm{C}$ for $30 \mathrm{~min}$ to recover the product. The composition of the reaction product was quantified using HPLC analysis.

\subsubsection{CAL B-PLA1 catalyzed hydrolysis of lecithin}

Concentrated soybean lecithin $(50 \mathrm{~g})$ and glycerol $(25 \mathrm{~g})$ at a molar ratio of $1: 4.5$, and water $(300 \mathrm{wt} \%$ of total substrates) were mixed and mechanically stirred $(500 \mathrm{rpm})$ at $50^{\circ} \mathrm{C}$. The reaction was initiated by adding a CAL B solution ( $10 \mathrm{wt} \%$ of lecithin) and $\mathrm{PLA}_{1}$ solution (10 $\mathrm{wt} \%$ of lecithin). The reaction mixture was incubated for $1 \mathrm{~h}$ at $50{ }^{\circ} \mathrm{C}$. At the end of the reaction, the reaction mixture was heated at $110{ }^{\circ} \mathrm{C}$ for $30 \mathrm{~min}$ to deactivate the enzymes. Water was removed through rotary evaporation at $80^{\circ} \mathrm{C}$ for $1 \mathrm{~h}$. Composition of the reaction product was quantified using HPLC analysis.

\subsubsection{Quantification of the glycerolyzed and hydrolyzed lecithins}

Quantitative analyses of the glycerolyzed and hydrolyzed products were carried out by HPLC (Agilent 1100) equipped with a silica gel column (Lichrospher Si 60, $5 \mu \mathrm{m}, 12 \mathrm{~cm}$ x $4 \mathrm{~mm}$, Merck) and evaporative light scattering detector (ELSD, Alltech 3300). Eluent A was chloroform/methanol/ ammonium hydroxide, 80/19.5/0.5 (v/v/v) and eluent B was chloroform/methanol/water/ammonium hydroxide, 60/34/5.5/0.5 (v/v/v/v). The gradient was: 0-14 min: linear from $\mathrm{A} / \mathrm{B}, 50 / 50$ to $100 \% \mathrm{~B}, 14-25$ min: hold $100 \%$ B, $25-30$ min: $100 \%$ B to A/B, 50/50 and $15 \mathrm{~min}$ at $\mathrm{A} / \mathrm{B}, 50 / 50$ for column regeneration. The flow rate of the eluent was $1 \mathrm{~mL} / \mathrm{min}$. The pressure of the nebulizer gas (air) in ELSD was maintained at 3.2 bars and the drift tube temperature was set at $40{ }^{\circ} \mathrm{C}$. The column temperature was also set at $40{ }^{\circ} \mathrm{C}$. The samples $(10 \mathrm{mg})$ were dissolved in $10 \mathrm{~mL}$ chloroform/methanol/water (70/25/5). $20 \mu \mathrm{L}$ of the sample were injected into the HPLC.

\subsubsection{HLB value of lyso lecithins with different acid values}

The HLB value was determined according to a method by Gupta et al., (1983) with slight modification. HLB standards $(5.0,5.2,5.4,5.6,5.8$, and 6.0) were prepared using cottonseed oil and turpentine. To measure the HLB values of lysolecithins, sample solutions were prepared (lysolecithins: standards: water $[1: 3: 16] \mathrm{w} / \mathrm{v} / \mathrm{v})$. These sample solutions were mixed for $5 \mathrm{~min}$ at $200 \mathrm{rpm} / \mathrm{min} .20 \mathrm{~mL}$ of the mixed solution were transferred to a graduated cylinder. Water separation from the mixtures was monitored for a period of $12 \mathrm{~h}$. The equation used for the determination of HLB value was:

$$
\begin{gathered}
\mathrm{X}=\frac{\mathrm{HLB}_{0}-\mathrm{HLB}_{1}}{\mathrm{HLB}_{2}-\mathrm{HLB}_{1}} \mathrm{X} \mathrm{M}_{0} \\
\mathrm{Y}=\mathrm{M}_{0}-\mathrm{X}
\end{gathered}
$$

Where $\mathrm{X}=$ weight $(\mathrm{mg})$ of high HLB value containing surfactant (Tween 80, turpentine), $\mathrm{M}_{0}=$ weight (mg) of standard oil required for the experiment, $\mathrm{Y}=$ low HLB value containing surfactant (span 80, cotton seed oil), $\mathrm{HLB}_{0}=\mathrm{HLB}$ of sample (concentrated lecithin or related product), $\mathrm{HLB}_{1}=$ required HLB of cotton seed oil, $\mathrm{HLB}_{2}=$ required HLB of turpentine.

\subsubsection{Emulsifying properties of concentrated and de-oiled lecithins}

2.2.9.1. Effects of calcium ion. Calcium ion tolerance of the emulsions was determined according to the method reported by Ye and Singh (2001) with slight modifications. Refined soybean oil $(50 \mathrm{~mL})$, calcium chloride solution $(0.1 \mathrm{wt} \%, 50 \mathrm{~mL})$ and varying amounts of lecithin were mixed and homogenized for $60 \mathrm{~min}$ at room temperature to ensure complete dispersion. The homogenized solution was kept in a measuring cylinder $(100 \mathrm{~mL})$ for a period of time. The amount of water separated from the emulsion at different storage times was recorded.

2.2.9.2. Effects of $p H$. The effects of $\mathrm{pH}$ on emulsifying properties were determined according to the method reported by Seung et al., (2011) with minor modifications. Soybean oil ( $50 \mathrm{~mL})$, aqueous solutions of different $\mathrm{pHs}$ (adjusted by $\mathrm{HCl}$ and $\mathrm{KOH}$ ) and lecithin/or modified lecithin products $(0.5 \mathrm{wt}$ $\%$ of total solution) were mixed. A coarse emulsion premix was prepared by homogenizing oil and aqueous phases using a high-speed blender for 2 min at room temperature. The premixed emulsions were further homogenized by five passes through a high pressure homogenizer. All the emulsions 
were then stored in amber glass bottles at $20{ }^{\circ} \mathrm{C}$ for up to 15 days. The amount of water separated from the emulsion at different storage times was recorded.

2.2.9.3 Aqueous solution. The emulsifying properties of concentrated and de-oiled lecithins in an aqueous solution was conducted according to the method by Aura et al., (1994) with slight modifications. Concentrated/de-oiled/modified lecithin ( $1 \mathrm{~g}, 1 \mathrm{wt} \%$ of total solution) was added to water $(100 \mathrm{~mL})$ and homogenized for $1 \mathrm{~min}$. The solution was kept in a measuring cylinder $(100 \mathrm{~mL})$ for a period of time. The amount of water separated from the emulsion at different storage time was recorded.

\section{RESULTS AND DISCUSSION}

\subsection{Characterization of the concentrated and modified soybean lecithin}

Table 1 shows the characterization of concentrated and modified soybean lecithin in terms of acetone insoluble matter, hexane insoluble matter, moisture content, acid value, PL distribution and fatty acid composition. Concentrated lecithin contains 40\% neutral lipids (36.1\% TAG and 3.9\% partial glycerides) and $60 \%$ of PLs (53\% PL and $7 \%$ Lyso PL). After the hydrolysis, the contents of neutral lipids and PLs were 40 (35.3\% TAG; 4.7\% partial glycerides) and 60\% (41.7\% Lyso PL 18.3\% PL), respectively. Glycerolyzed lecithin contains higher amounts of partial glycerides $(33.5 \%)$ and minor amount of TAG (2.7\%). Lyso PLs and PL contenst in glycerolyzed lecithins were 52 and $11.8 \%$, respectively.

The PL compositions of concentrated lecithin, aqueous-hydrolyzed lecithins (lysolecithin-1), solvent-hydrolyzed lecithins (lysolecithin-2) and glycerolyzed lecithin were different from each other (Table1). Concentrated lecithin contains approximately equal amounts of PC, PE and PI $(\sim 30 \%)$ and a small amount of PS $(<10 \%)$. After the enzymatic hydrolysis and glycerolysis the amount of Lyso PLs increased $(>50 \%)$ in lysolecithin 1 , lysolecithin 2 and glycerolyzed lecithins. All the enzymes have higher affinity for Zwitterionic PLs (PC and PE) resulting in a significant $(\mathrm{P}<0.05)$ increment in their lysocounterparts (Lyso PC and Lyso PE). In contrast, anionic PLs such as PA are almost unmodified. The reason for enzymes exhibiting high selectivity towards Zwitterionic PLs could be their tertiary structure. That means the tertiary structure of enzymes is more favorable to react with these PLs. The fatty acid profiles were similar for concentrated and modified lecithins. The major fatty acids were linoleic $(>50 \%)$ and palmitic acids $(>20 \%)$. The remaining fatty acids were comprised of stearic, oleic and linolenic acids.

\subsection{Determination of HLB values}

The HLB values of the lysolecithin products are shown in Table 2. Lysolecithin 1 (acid value approximately 60) was highly hydrophilic with a HLB of approximately 7.6 to 8.0. Meanwhile, lysolecithin 2 (acid value of approximately 55) was more hydrophobic than lysolecithin 1 with HLB of approximately 6.5 to 7.0. The degree of hydrolysis of lysolecithins (indirectly acid value) leads to the differences in HLB values which means the higher hydrolyzed lecithins will have a high lyso PL content and HLB and vice-versa (Estiasih 2013; www.solae.com). In general, based on the requirement of hydrophilicity the degree of hydrolysis will be varied starting from $20 \%$ to $60 \%$. If the hydrolysis is between $20-30 \%$ the hydrolysis can be considered minor hydrolysis.

\subsection{Emulsifying properties of concentrated and de-oiled lecithins}

\subsubsection{Effect of calcium ion concentration on emulsifying properties of lecithins}

The calcium ion tolerance of PL and Lyso PL was in the following ascending order: concentrated lecithin < powder lecithin < lysolecithin from crude gum solution $\approx$ lysolecithin from concentrated

TABLE 2. HLB values of modified lecithins with different acid values

\begin{tabular}{lcc}
\hline \multicolumn{3}{c}{ HLB values of modified lecithins with different acid values } \\
\hline Types of lecithins & $\begin{array}{c}\text { Acid value } \\
\text { (mg KOH/g) }\end{array}$ & $\begin{array}{c}\text { HLB value } \\
\text { range }\end{array}$ \\
\hline Lysolecithins 1 $^{\text {a }}$ & 60.6 & $7.6-8.0$ \\
& 60.3 & $7.6-8.0$ \\
& 54.8 & $6.5-7.0$ \\
& 53.6 & $6.5-7.0$ \\
Lysolecithins 2 $^{\mathrm{a}}$ & 52.8 & $6.0-6.5$ \\
& 48.6 & $5.5-5.9$ \\
Lecithin with minor $_{\text {hydrolysis }}^{\mathrm{a}}$ & 45.7 & $5.2-5.6$ \\
& 44.0 & $5.0-5.5$ \\
& 43.0 & $5.2-5.5$ \\
& 41.8 & $5.1-5.4$ \\
Glycerolyzed Lecithin & 40.7 & $5.0-5.4$ \\
Concentrated Lecithin & 39.0 & $5.0-5.3$ \\
\hline
\end{tabular}

${ }^{\mathrm{a} A r i t h m e t i c ~ m e a n s ~ o f ~ t r i p l i c a t e ~ d e t e r m i n a t i o n s ~ w i t h ~ t h e i r ~}$ confidence interval at $95 \%$. Minor hydrolysis using both solvent and aqueous media. These are the values of different experiments (batches) with different acid values. 
lecithin < lysolecithin powder from lysolecithin (Figure 1A). The concentrated lecithin and its powder exhibited poor performance (at all the studied concentrations) in high calcium ion solution due to their higher sensitivity towards calcium ions. Lysolecithin has better emulsifying properties than concentrated lecithin-based emulsion indicating better calcium tolerance towards calcium ions. This is in agreement with previous findings that showed Lyso PE-stabilized emulsion did not flocculate in the presence of calcium ions and milk protein (Duin et al., 1963; Hoof et al., 2005).

\subsubsection{Effects of $p H$ on emulsifying properties of concentrated and de-oiled lecithin}

At highly acidic conditions ( $\mathrm{pH}=2)$, the ascending order of emulsion stability was as follows: concentrated lecithin < powder lecithin < lysolecithin from crude gum solution $\approx$ lysolecithin from concentrated lecithin < lysolecithin powder from lysolecithin (Figure 1B). Apart from lysolecithins prepared from crude gum solution and the concentrated lecithin, the powdered lysolecithin also had good emulsifying properties at $\mathrm{pH} 2$ (strongly acidic condition). Whereas, when the concentrated lecithin, powdered lecithins were used as emulsifiers the oil phase in the emulsion was separated at a $24 \mathrm{~h}$ time period which led to complete demulsification of the emulsion. This finding is in agreement with previous observations that lysolecithin improves the stability of emulsion with high salt and over a wide range of $\mathrm{pH}$. Therefore, it is used as an ingredient in foods requiring longer shelf life (Aoi, 1990).

At moderate acidity condition $(\mathrm{pH}=4)($ Fig $1 \mathrm{C})$, the ascending order of emulsion stability observed was as follows: concentrated lecithin $\approx$ powder lecithin $<$ lysolecithin from crude gum solution $\approx$ lysolecithin from concentrated lecithin < lysolecithin powder from lysolecithin. At the moderate to highly acidic conditions $(\mathrm{pH}<5)$ the lysolecithin and its (a)

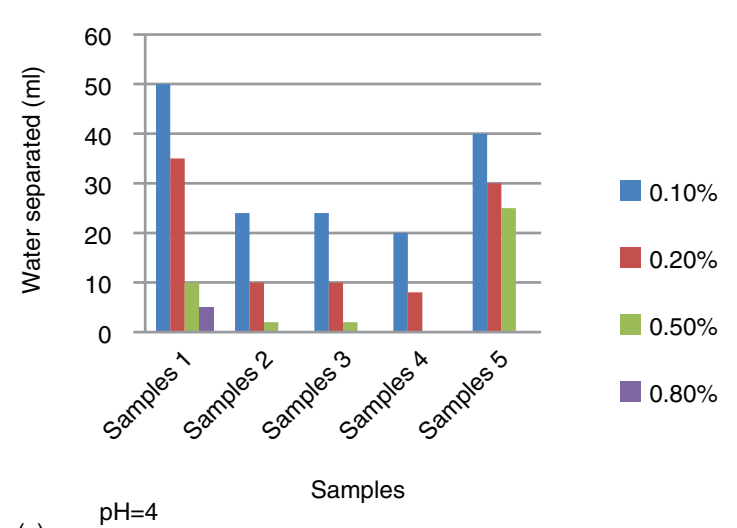

(c)

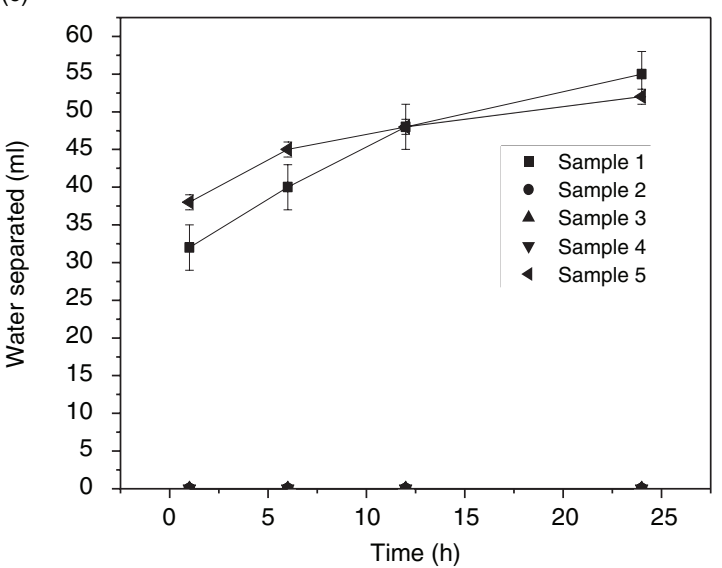

(b) $\mathrm{pH}=2$

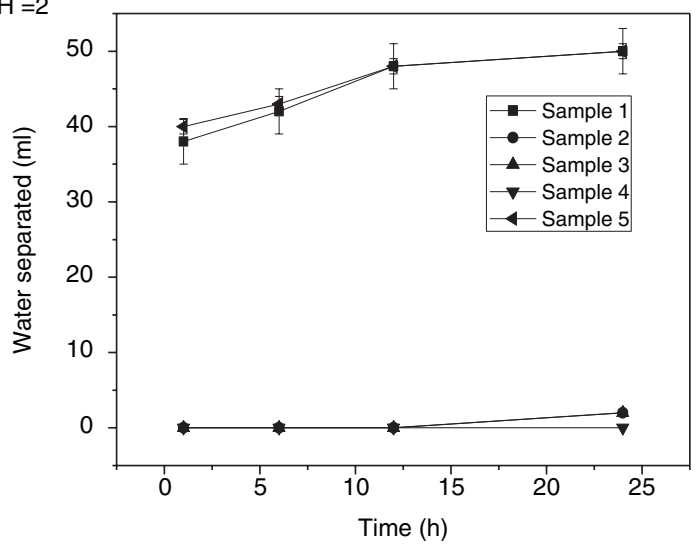

(d)

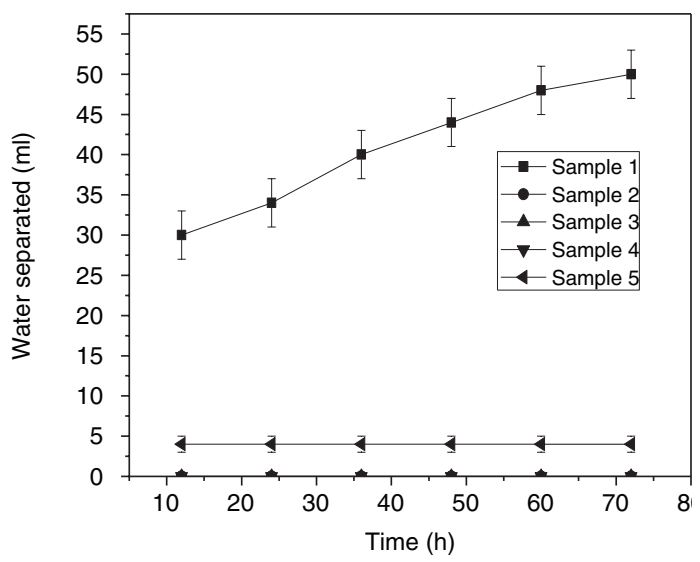

FIGURE 1. A) Effect of calcium ion on the stability of emulsions at different lecithin concentrations (at 10 min time periods); (B and C) Effect of $\mathrm{pH}$ on stability of emulsion; sample 1, concentrated lecithin (0.5\%); sample 2, Lysolecithin from crude gum solution $(0.5 \%)$; sample 3 , lysolecithin from con lecithin $(0.5 \%)$; sample 4 , lysolecithin powder $(0.5 \%)$; sample 5 , powdered lecithin $(0.5 \%)$; D) Stability of aqueous based emulsion system. Each value is the average of two determinations. Lysolecithin samples were stable for at least 12 days. All values are arithmetic means of duplicate determinations. 
powder exhibited good performance in stabilizing the emulsification system and the performance was much better than concentrated lecithin and its powder.

\subsubsection{Aqueous solution}

The emulsifying properties of concentrated and de-oiled lecithins are shown in Figure 1D. Powdered lysolecithin exhibited superior emulsifying properties. This is followed by lysolecithin from concentrated lecithin, lysolecithin from crude gum solution $>$ powder lecithin $>$ concentrated lecithin. It was observed that lysolecithin solutions were stable at least for 12 days. As lysolecithin exhibits high moisture retention, its solubilizing property, its lipophilic and hydrophilic moiety's holding nature and emulsifying power are excellent. Especially, enzymatic hydrolyzed lecithin possesses technological and commercial advantages over native lecithins such as enhanced $\mathrm{O} / \mathrm{W}$ emulsifying property, increased emulsion stability under acidic conditions and in the coexistence with salts, improved capability to bind proteins and starch and excellent mold- or pan-releasing property (Hirai et al., 1998; Erickson, 2008). Consequently, the demand for lysolecithins has increased in recent years.

The less hydrolyzed lecithins (lower AV and HLB) were ignored for the evaluation in the present study as their properties are expected to be more or less similar to normal concentrated lecithin. In general, lecithins that exhibit HLB values between 4-6, 7-9 and 8-10 are considered as water in oil (w/o) emulsifiers, wetting agents and oil in water $(\mathrm{o} / \mathrm{w})$ emulsifiers, respectively. In our case standard concentrated lecithins, lecithins with minor hydrolysis, lysolecithin 2 falls in the range of 4-6 HLB values and therefore, they are expected to have applications in w/o emulsions such as margarine, spreads, icings, frostings and petroleum emulsions. On the other hand, the optimally hydrolyzed lecithin such as lysolecithin 1 falls in the range of 8-10 HLB values and therefore, they will have the application in $\mathrm{o} / \mathrm{w}$ emulsions such as mayonnaise, infant formulas, and hand and body lotions. Since the glycerolyzed lecithin also exhibited HLB near to 7.0, this product can be suitable in o/w emulsions and it will not be suitable for w/o emulsions.

\section{CONCLUSIONS}

The food grade emulsifiers such as lysolecithins, hydrolyzed lecithin and glycerolyzed lecithin were prepared using simple enzymatic methods. The optimally hydrolyzed lecithin was examined at high calcium ion, low $\mathrm{pH}$, and aqueous solutions and compared with commercially available standard lecithin-based emulsifiers. Overall, lysolecithin powder was proven to be the best emulsifier due to its high moisture retention, solubilizing property and enhanced o/w emulsifying properties. Further, it is the best due to its high emulsifying efficiency under acidic conditions and also in high calcium ion concentrations.

\section{ACKNOWLEDGMENTS}

The authors would like to thank the Wilmar Global R \& D Center for permission to publish this work.

\section{REFERENCES}

Aliqian Y, Harjinder S. 2001. Interfacial composition and stability of sodium caseinate emulsions as influenced by calcium ions. Food Hydrocolloids 15, 195-207. http://dx.doi. org/10.1016/S0268-005X(00)00065-5

AOCS. 2001. In: DEFirestone (Ed.) Official methods and recommended practices of $A O C S$ ( 4 th ed.) Illinois: The American Oil Chemists Society AOCS Press.

Aoi N. 1990. Soy lysolecithin. Yukagaku 39, 10-15.

Aura AM, Forssell P, Mustranta A, Suortti T, Poutanen K. 1994. Enzymatic hydrolysis of oat and soya lecithin: Effects on functional properties. J. Am. Oil Chem. Soc. 71, 887-891. http://dx.doi.org/10.1007/BF02540468

Becart J, Chevalier C, Biesse JP. 1990. Quantitative analysis of phospholipids by HPLC with a light-scattering evaporating detector - application to raw materials for cosmetic use. J. High Resol. Chromatog. 13, 126-129. http://dx.doi. org/10.1002/jhrc. 1240130210

De Maria L, Vind J, Oxenbøll KM, Svendsen A, Patkar S. 2007. Phospholipases and their industrial applications. Applied Microbiol. Biotechnol. 74, 290-300. http://dx.doi. org/10.1007/s00253-006-0775-x

Duin H, Westdorp P, Weiske Th, Reissmann W. 1963. Phosphatide antispattering agent for margarine. British Patent 1491952.

Erickson MC. 2008. Chemistry and function of phospholipids In: Akoh CC, Min DB (eds) Food lipids: chemistry nutrition and biotechnology, Chapter 23rd. edn. CRC Press Boca Raton, 39-62.

Estiasih T, Kgs, Ahmadi Ginting E, Priyanto AD. 2013. Modification of soy crude lecithin by partial enzymatic hydrolysis using phospholipase $\mathrm{A}_{1}$. Int. Food Res. J. 20, 843-849.

Fujita S, Suzuki K. 1990. Surface activity of the lipid products hydrolyzed with lipases and phospholipase A, J. Am. Oil Chem. Soc. 67, 1008-1014. http://dx.doi.org/10.1007/ BF02541867

Gupta RK, James K, Smith FJ. 1983. Sucrose esters and sucrose ester/glyceride blends as emulsifiers. J. Am. Oil Chem. Soc. 60, 862-869. http://dx.doi.org/10.1007/BF02787451

Haas MJ, Scott K, Janssen G.1994. Enzymatic phosphatidylcholine hydrolysis in organic solvents: An examination of selected commercially available lipases. J. Am. Oil Chem. Soc. 71, 483-490. http://dx.doi.org/10.1007/BF02540658

Haas MJ, Cichowicz DJ, Phillipis J, Moreau R. 1993. The hydrolysis of phosphatidylcholine by an immobilized lipase optimization of hydrolysis in organic solvents. J. Am. Oil Chem. Soc. 70, 111-117. http://dx.doi.org/10.1007/BF02542611

Hirai H, Sono R, Koh H. 1998. Process for manufacturing vegetable lysolecithins. European Patent EP0870840.

Hoof C.'t, Van den Kommer M, Segers JC. 2005. Food composition suitable for shallow frying comprising sunflower lecithin. European Patent EP1607003.

Kim JK, Kim MK, Chung GH, Choi CS, Rhee JS. 1997. Production of lyso phospholipid using extracellular phospholipase $\mathrm{A}_{1}$ from Serratia SpMK1. J. Microbiol. Biotechnol. 7, 258-261.

Kudo S, Nishi E. 1990. Surfactant and process for producing the same PCT. International Appl. WO 9011823. 
Mustranta A, Forsell P, Poutanen K. 1995. Comparison of lipases and phospholipases in the hydrolysis of phospholipids. Process Biochemistry 30, 393-401. http://dx.doi. org/10.1016/0032-9592(94)00030-1

Nakai E, Suzuki K, Sato S, Kato M. 1988. Method for enzymatic decomposition of phospholipid. Jpn. Kokai Tokkyo Koho JP 63044883

Nieuwenhuyzen WV, Tomas MC. 2008. Update on vegetable lecithin and phospholipid technologies. European J. Lipid Sci. Technol. 110, 472-486. http://dx.doi.org/10.1002/ ejlt.200800041

Nieuwenhuyzen WV. 1981. The industrial uses of special lecithins. J. Am. Oil Chem. Soc. 58, 886-888. http://dx.doi. org/10.1007/BF02659651

Sarney DB, Fregpane G, Vulfson EN. 1994. Lipase-catalyzed synthesis of lysophospholipids in a continuous bioreactor.
J. Am. Oil Chem. Soc. 71, 93-96. http://dx.doi.org/10.1007/ $\mathrm{BF} 02541478$

Schmitt H, Heirman M, Brüse F, Schneider M, Van Der Sype J. 2005. Enzymatic production of hydrolyzed lecithin products. WIPO Patent Application WO/2005/100579.

Seung JC, Eric AD, Lulu H, Popplewell LM, Hang X, David JM. 2011. Formulation and properties of model beverage emulsions stabilized by sucrose mono palmitate: Influence of $\mathrm{pH}$ and lysolecithin addition. Food Res. Int. 44, 30063012. http://dx.doi.org/10.1016/j.foodres.2011.07.007

Ye A, Singh H. 2001. Interfacial composition and stability of sodium caseinate emulsions as influenced by calcium ions. Food Hydrocolloids 15, 195-207. http://dx.doi.org/10.1016/ S0268-005X(00)00065-5

Yesair DW, 1997. Methods for making lysophosphatidylcholine PCT. International Appl. WO 9728270. 